\title{
Analysis of Vibration and Noise on Vibrating Screen at PT. Mifa Bersaudara
}

\author{
Kamarullah $^{1, a)}$, Herdi Susanto ${ }^{2, b)}$ \\ ${ }^{1}$ Student of Mechanical Engineering, Teuku Umar University, Meulaboh, West Aceh, Indonesia \\ ${ }^{2}$ Lecturers of Mechanical Engineering, Teuku Umar University, Meulaboh, West Aceh, Indonesia \\ e-mail : a) Kamarullah344@gmail.com, b) Herdisusanto@utu.ac.id
}

\begin{tabular}{|c|c|}
\hline ARTICLE INFO & ABSTRACT \\
\hline $\begin{array}{l}\text { Article history: } \\
\text { Accepted }\end{array}$ & $\begin{array}{l}\text { The purpose of this study was to analyze the level of vibration and } \\
\text { noise on the Equipment Vibrating screen crusher FC } 02 \text { at PT. MIFA }\end{array}$ \\
\hline $\begin{array}{l}\text { Keywords: } \\
\text { Vibrating Screen crusher FC } 02 \\
\text { Vibration } \\
\text { Noise } \\
\text { PT Mifa Bersaudara }\end{array}$ & $\begin{array}{l}\text { Bersaudara. Vibration is measured using a vibration meter, noise is } \\
\text { measured by a digital sound level meter. Measurements are made on the } \\
\mathrm{x}, \mathrm{y} \text { and } \mathrm{z} \text { axes at each measurement point. The results showed that the } \\
\text { value of the vibration level on the Vibrating screen crusher FC } 02 \text { on the } \\
\mathrm{x} \text {-axis with the velocity value of } 28.56 \mathrm{~mm} / \mathrm{s} \text {, the y-axis value of } 29.82 \\
\mathrm{~mm} / \mathrm{s} \text { and the z-axis velocity value of } 25.46 \mathrm{~mm} / \mathrm{s} \text {. While the Acceleration } \\
\text { value on the x-axis is } 20.7 \mathrm{~m} / \mathrm{s} 2 \text { the value is } 30.86 \mathrm{~m} / \mathrm{s} 2 \text { on the y and } \mathrm{z} \\
\text { axes of } 21.42 \mathrm{~m} / \mathrm{s} 2 \text {. While the noise value indicates that the average } \\
\text { value on the right side is } 99.6 \mathrm{dBA} \text { on the right side and } 101.7 \mathrm{dBA} \text { on the } \\
\text { left side. Efforts were made to overcome the problem, namely by not } \\
\text { operating the VSC FC } 02 \text { exceeding the recommended maximum limit of } \\
60 \text { dBA and the maximum allowed which is } 70 \mathrm{dBA} \text { so as to prevent } \\
\text { problems of comfort, health, and safety at work. Operators and employees } \\
\text { are advised to stay at the location for no more than } 15-30 \text { minutes, if more } \\
\text { than that time must use safety earmuffs. }\end{array}$ \\
\hline
\end{tabular}

Copyright (C) 2021 Politeknik Aceh Selatan. All rights reserved.

\section{Introduction}

Aceh province has a potential source of coal energy spread over several areas such as Meulaboh, Aceh Barat, Singkil, and Nagan Raya. The mining sector is the most important sector in Aceh Province considering the role of the sector in the formation of GRDP which reaches 30.95\% (BKPM Aceh, 2012). After the tsunami, the south west of aceh has great prospects for development with the existing advances and technology, especially in the mining industry so that many large companies in this field have set up companies in the south west of Aceh. PT. MIFA Bersaudara has a concession area of 3,134 hectares (Ha) in the district of West Aceh which is valid until 2025 (PT. Mifa Bersudara Profile, 2021). [6] The importance of the vibration and noise measurement test caused by this Vibrating screen tool where noise is the occurrence of an unwanted sound so that it can cause disturbances to comfort and health (Saputra, 2007). [7] Noise can cause damage to the sense of hearing, either permanent or temporary which is influenced by the frequency and intensity of exposure to noise (Kusmindari, 2008). While vibration is a uniform motion that occurs repeatedly from an object in a fast tempo. Vibration caused when the machine is operated will cause mechanical vibration (Suhardi, 2008). [8] Vibrating screen it self is a tool used to separate the meterial size resulting from the crushing process based on the size of the opening in millimeters $(\mathrm{mm})$ or commonly referred to as mesh [1]. (Fadili, 2020). In accordance with the Decree of the Minister of Health concerning Office and Industrial Work Environment No. 1405/MENKES/SK/XI/2002 states that the noise threshold is $85 \mathrm{~dB}$ for 8 hours of work/day. Therefore, it is necessary to conduct research to determine the extent of the vibration and noise generated by this Vibrating screen tool because the impact will be able to damage hearing if left in the long term. Noise can cause increased fatigue and impaired concentration of workers so that errors occur while working. Continuous work in noisy places results in permanent and irreversible loss of hearing, noise comes from machinery and production equipment used in a company. Thus this research needs to be done to ensure occupational safety and health. 


\section{Research Method}

The object of measurement in this study is the Vibrating Screen crusher FC 02 which is located at PT. MIFA Bersaudara operates in Aceh Barat District, Aceh Province. The vibration measuring instrument used is a vibrationmeter and a noise measuring instrument is a Sound Level Meter. Measurements were made on the $\mathrm{x}, \mathrm{y}$ and $\mathrm{z}$ axes of each measurement point with a measuring distance of 1 meter. Measurements were made from $11 \mathrm{~s} / \mathrm{d} 13$ March 2021. The measured vibration parameters are the acceleration (acceleration), and speed (velocity). While the noise parameter is decibels (dBA). Measurement data processing is carried out using the Microsoft Excel Application in tabular form and is represented in the form of processing results compared to the noise standard from the Decree of the Minister of Manpower Number : KEP51/MEN/1999 concerning Threshold Values for Physical Factors in the Workplace. As well as the standard noise criteria set by various parties based on the Regulation of the Minister of Health of the Republic of Indonesia No. 718/Men/Kes/Per/XI/1987, concerning noise related to health and then draw conclusions.

\section{Results and Discussion}

Problem Identification Results

Based on an internship for 6 months on a Vibrating screen tool at PT. MIFA Bersaudara. Noise measurements for each point were repeated 10 times with an interval of 5 seconds for data collection in order to obtain accurate results.

Table 1. Noise zone division by minister of health

\begin{tabular}{llcc}
\hline \multirow{2}{*}{ No. } & \multirow{2}{*}{ Zone } & \multicolumn{2}{c}{ Noise Level (dBA) } \\
\cline { 3 - 4 } & & Recommended maximum & Maximum allowed \\
\hline 1 & $\mathrm{~A}$ & 35 & 45 \\
2 & $\mathrm{~B}$ & 55 & 55 \\
3 & $\mathrm{C}$ & 60 & 60 \\
4 & $\mathrm{D}$ & & 79 \\
\hline
\end{tabular}

Source: (Regulation of the Minister of Health of the Republic of Indonesia No. 718/Men/Kes/Per/XI/1987, concerning noise related to health in Hendrawan, 2020) [2].

Based on the table above, it is explained that Zone A is intended for research sites, hospitals, health care facilities and so on, Zone B is intended for housing, education, recreation, and the like, Zone $\mathrm{C}$ is intended for offices, shops, trade, markets, and the like and Zone D industry, factories, railway stations, bus terminals, and the like. In this study, to analyze the vibration and noise on the Vibrating screen work tool at PT. The MIFA Siblings which are classified in Zone D have the recommended maximum of $60 \mathrm{dBA}$ and the maximum allowed which is $79 \mathrm{dBA}$. The following table shows the maximum time to work.

Table 2. Maximum Working Time

\begin{tabular}{ccc}
\hline No. & Noise Level (dBA) & Daily Exposure \\
\hline 1 & 85 & 8 hours \\
2 & 88 & 4 hours \\
3 & 91 & 2 hours \\
4 & 94 & 1 hour \\
5 & 97 & 30 minutes \\
6 & 100 & 15 minutes \\
\hline
\end{tabular}

Source: (Regulation of the Minister of Health of the Republic of Indonesia No. 718/Men/Kes/Per/XI/1987, concerning noise related to health in Hendrawan, 2020). [2].

In the measurement of vibration using a vibration meter. The measurement of movement is carried out on the frame or holder of the Vibrating screen work tool which is in direct contact with the operator whose machine is being operated. Vibration measurements are carried out in the direction of the $\mathrm{x}$-axis, $\mathrm{y}$-axis and $z$-axis at each measurement point. Measurements were repeated 5 times at each engine speed after which a vibration analysis was carried out and compared with the allowable vibration exposure limit standard. Noise level measurements were carried out at the noise source, namely around the nearest point on the FC 02 Vibrating screen crusher while operating at PT. Mifa Bersaudara. For more details can be seen in Figure 1 below: 


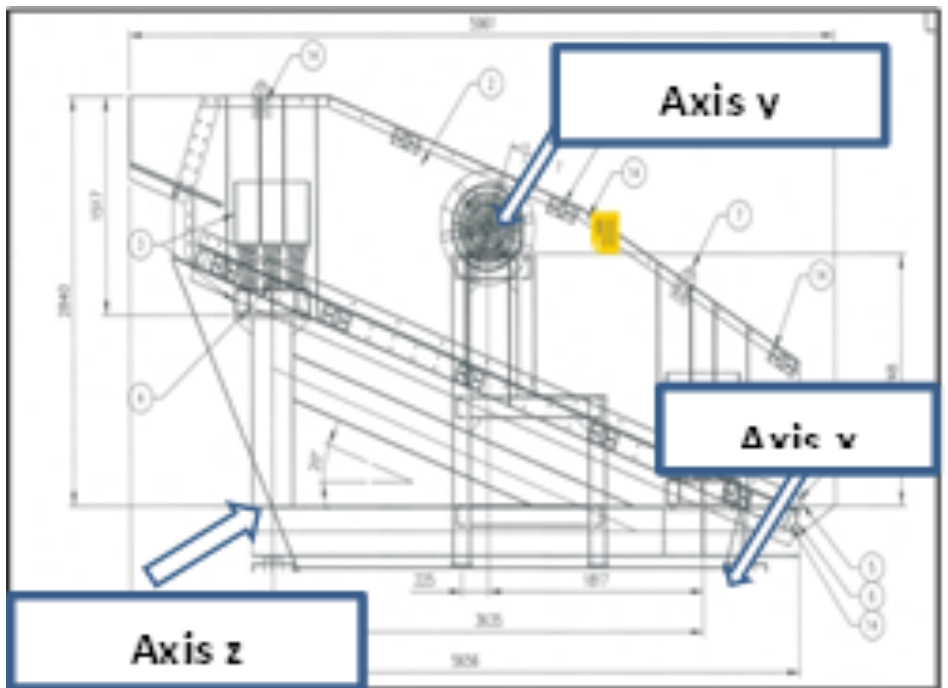

Source: Internship Primary Data, 2021

Picture.1 Vibrating Screen crusher FC 02 (Front View) by point of measurement

\section{Analysis of Vibration Level on Vibrating Screen crusher FC 02 Acceptable time threshold (TVDV)}

The acceptable time threshold is the time that is still allowed to meet the accepted exposure standard. In other words, the TVDV calculation is one way to find out the maximum time obtained in a vibration so that it can provide information and even minimize the negative impact of the vibration (Kurniawati, 2013) [3].

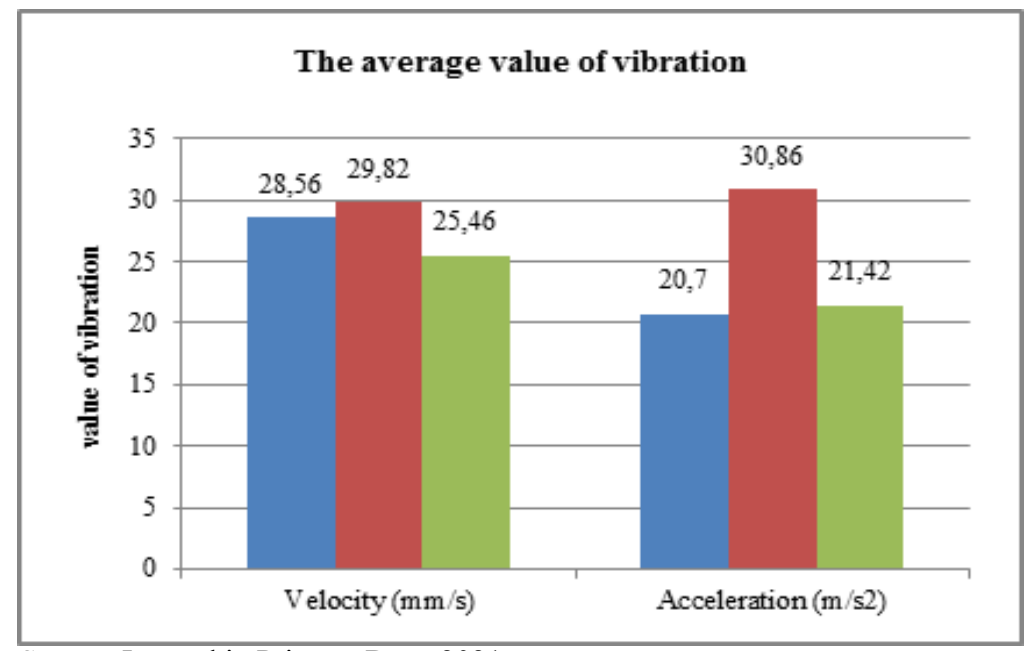

Source: Internship Primary Data, 2021

Picture. 2 The average value of vibration on vibrating screen crusher FC 02

Based on the graphic above, the vibration value on the Vibrating Screen work tool, the x-axis vibration that is produced at the velocity value of $28.56 \mathrm{~mm} / \mathrm{s}$, has increased on the y-axis with a velocity value of $29.82 \mathrm{~mm} / \mathrm{s}$ and has decreased on the z-axis with velocity value is $25,46 \mathrm{~mm} / \mathrm{s}$. While the acceleration (Acceleration) on the $\mathrm{x}$-axis of $20.7 \mathrm{~m} / \mathrm{s}^{2}$ surge increase in the value of Acceleration vibration average reach of $30.86 \mathrm{~m} / \mathrm{s}^{2}$ on the $y$-axis and again decreased in the z-axis with a bunch of value Acceleration vibration an average of $21.42 \mathrm{~m} / \mathrm{s}^{2}$

Based on the vibration standard of the Decree of the Minister of Health Number 1405/MENKES/SK/XI/2002 concerning vibrations related to health, it is referred to in Manullang, 2015. [5] Where mechanical vibrations can be interpreted as vibrations caused by mechanical devices, and some of these vibrations reach the human body so that it can cause unwanted disturbances by the human body. Thus the reference in the study obtained refers to the vibration threshold according to the standard, for more details, it can be seen in the following table: 
Table 3. Threshold standard on vibration

\section{Total time/Working day}

4 Hours and less than 8 hours

2 Hours and less than 4 hours

1 hour and less than 2 hours

Less than 1 hour

\section{Acceleration Value At}

Dominant Frequency

\section{Meters per second squared Grams (m/s2)}

gram

$\begin{array}{cl}4 & 0.4 \\ 6 & 0.61 \\ 8 & 0.81 \\ 12 & 1.22\end{array}$

Source: (Standard vibration Minister of Health Decree No. 1405/MENKES/SK/XI/2002 regarding vibration related to health is referred to in Manullang, 2015) [7].

Thus referring to the vibration standard of the Decree of the Minister of Health Number 1405 / MENKES / SK / XI / 2002 concerning vibrations related to health, it is referred to in Manullang, 2015. [5] Then it is harmonized with data collection on the research internship process at PT. Mifa Bersaudara obtained data as follows:

According to the data obtained from the results of research on internships at PT. Mifa Bersudara can be produced that the duration of vibration is in accordance with the accepted standard with the number of working days per working day where the category is 4 hours and less than 8 hours with the acceleration value (vibration) at a dominant frequency of $4 \mathrm{~m} / \mathrm{s}^{2}$. On the $\mathrm{x}$-axis, it is found that the average is $0.3 \mathrm{~m} / \mathrm{s}^{2}$ which is normal in accordance with the permissible standards for industrial factory vibration. Similarly, the z-axis results in an average of $0.3 \mathrm{~m} / \mathrm{s}^{2}$ which is normal according to the permissible standard. However, unlike the $\mathrm{y}$-axis is generated that an average of $0.5 \mathrm{~m} / \mathrm{s}^{2}$ which meets $/$ not normal according to the standard are allowed.

\section{Noise Level Analysis on Vibrating Screen Tools}

From the results of measurements made during the internship, the noise measurement at a predetermined point around the Vibrating Screen tool is known to be the average noise. In calculating the noise level on the Vibrating Screen work tool, 3 measurement points are carried out with 5 repetitions. In these measurements, 3 measurement points were carried out where the noise source came from the Vibrating Screen work tool. At the first point the measurement is carried out on the right side of the end of the Vibrating Screen and at the second measurement is carried out on the left side close to the source of the noise part of the Vibrating Screen.

The noise level at each measurement point by doing 5 repetitions on each right and left side has an average value ranging from 98.7-104.1 dBA. The highest noise level is located at the point closest to the noise source on the Vibrating Screen tool (left side) with a noise level of 104.1 dBA. This is because the noise measurement point on the right is the source of noise on the Vibrating Screen tool. Meanwhile, the lowest noise level is at the right side of the noise measurement point, which is the farthest point from the noise source, which is $98.7 \mathrm{dBA}$. Based on the measured noise level, the motor rotation speed on the Vibrating Screen work tool is directly proportional to the noise level. In accordance with Susanto's research (2021) [9] stated that the noise level of the electric motor and the centrifugal tube of the coconut milk production machine with a capacity of 10 liters per hour can be concluded that the noise level value of the production machine meets the noise standard level required by OSHA 1978, where the engine noise level The maximum production is at $75 \mathrm{db}$, while the maximum required by OSHA 1978 is at $85 \mathrm{db}$. For more details, see table 4 which is presented below.

Table 4. Average noise intensity on the Vibrating Screen

\begin{tabular}{ccccc} 
Noise Side & \multicolumn{2}{c}{ Measurement Point on Vibrating Screen (dBA) } & \multirow{2}{*}{$\begin{array}{c}\text { Overall Average } \\
\text { (dBA) }\end{array}$} \\
\cline { 2 - 3 } & $\mathbf{1}$ & $\mathbf{2}$ & $\mathbf{3}$ & \\
\hline Right & 100.5 & 98.7 & 99.6 & 99.6 \\
Left & 104.1 & 100.1 & 101 & 101.7 \\
\hline
\end{tabular}

Source: Internship Primary Data, 2021 
Based on the table above, it is explained that the overall average at the three measurement points with two right and left sides shows that the overall average noise on the vibrating screen work tool is $99.6 \mathrm{dBA}$ on the right side and 101.7 on the left side. dBA noise. Meanwhile, based on the National Standardization Agency (BSN) in SNI 16-7063-2004 and the Regulation of the Minister of Health of the Republic of Indonesia No. 718/Men/Kes/Per/XI/1987, regarding noise related to health in Hendrawan, 2020 [2] states that in the Zone D category of industries, factories, railway stations, bus terminals, and the like. The maximum recommended threshold value is $60 \mathrm{dBA}$ and the maximum allowable value is $79 \mathrm{dBA}$ with the maximum working time the noise threshold value is $85 \mathrm{~dB}$ which is considered safe for most workers when working 8 hours/day or 40 hours/week. It can be presented in the following graphic image.

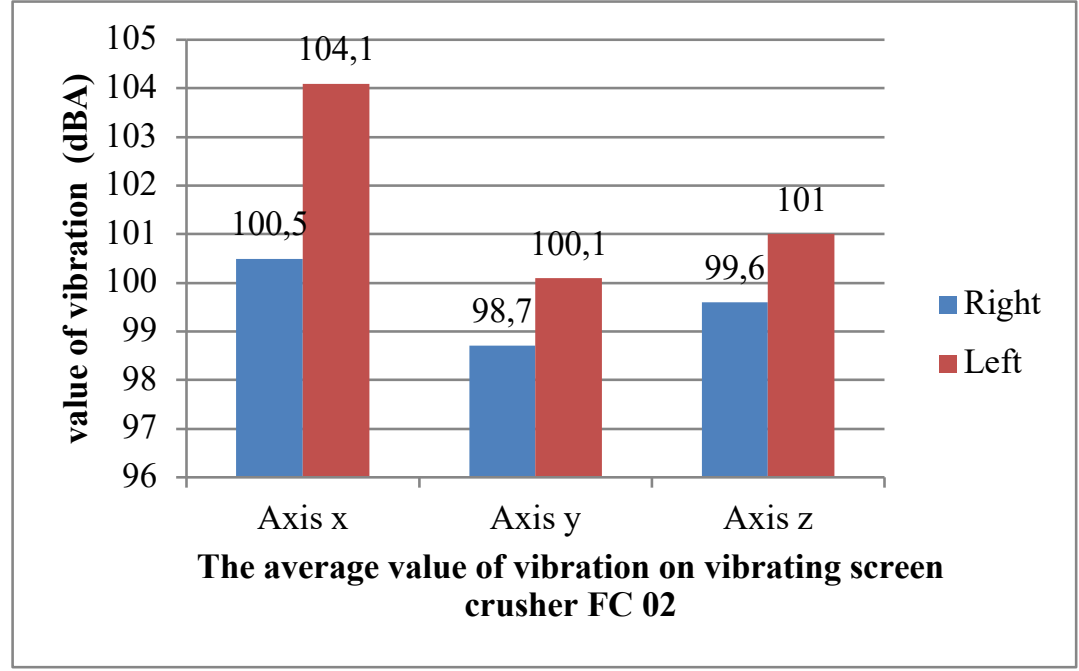

Source: Internship Primary Data, 2021

Picture. 3 Average noise value of vibrating screen crusher FC 02

During the process that occurs in the field while doing an internship at PT. MIFA Bersaudara, for the average noise value on the vibrating screen tool, the noise is $99.6 \mathrm{dBA}$ on the right side and $101.7 \mathrm{dBA}$ on the left. In accordance with the standardization of the Regulation of the Minister of Health of the Republic of Indonesia No. $718 / \mathrm{Men} / \mathrm{Kes} / \mathrm{Per} / \mathrm{XI} / 1987$, regarding noise related to internal health (Hendawan, 2020) [2] is categorized by the noise level which means on the right side of the work tool. The vibrating screen shows that $99.6 \mathrm{dBA}$ can only be exposed to 30 minutes of exposure per day and on the left side of $101.7 \mathrm{dBA}$ means that only 15 minutes per day are exposed to noise exposure from this vibrating screen tool. For more details can be seen in the following table.

Table 5. The permissible duration of hearing noise on the Vibrating Screen

Noise Side
Average Noise Level (dBA)
Allowed Listening Length (minutes/day)

\begin{tabular}{ccc}
\hline Right & 99.6 & 30 \\
Left & 101.7 & 15 \\
\hline
\end{tabular}

Source: Internship Primary Data, 2021

Based on table 5 above, the permissible hearing time for noise on Vibrating Screen crusher FC 02 is in accordance with the reference to the Regulation of the Minister of Health of the Republic of Indonesia No. $718 / \mathrm{Men} / \mathrm{Kes} / \mathrm{Per} / \mathrm{XI} / 1987$, concerning noise related to health. So that the use of work tools on the Vibrating Screen should not exceed the allowable length of hearing, which is 15-30 minutes per day. The use of work tools on the Vibrating Screen should not exceed the time limit allowed to maintain the occupational health and safety of the operators and employees. 


\section{Conclusion}

The results of the final report of the internship carried out at PT. MIFA Bersaudara can be concluded that; Measurement of vibration and noise of work tools Vibrating Screen crusher FC 02 is carried out in the direction of the x-axis, y-axis and z-axis at each measurement point. Based on the vibration value on the Vibrating Screen crusher FC 02 work tool, the $x$-axis vibration is generated at a velocity value of $28.56 \mathrm{~mm} / \mathrm{s}$, a y-axis value of $29.82 \mathrm{~mm} / \mathrm{s}$ and a z-axis velocity value of 25.46 $\mathrm{mm} / \mathrm{s}$. While the acceleration on the x-axis of $20.7 \mathrm{~m} / \mathrm{s} 2$ has an increase in value of $30.86 \mathrm{~m} / \mathrm{s} 2$ on the $\mathrm{y}$ axis and a decrease in the $\mathrm{z}$ axis of $21.42 \mathrm{~m} / \mathrm{s} 2$. The noise value on the Vibrating Screen crusher FC 02 work tool shows that the overall average with the two right and left sides is $99.6 \mathrm{dBA}$ on the right side and $101.7 \mathrm{dBA}$ on the left side of the noise.

\section{Acknowledgment}

Operators are advised to measure noise levels and not to operate the Vibrating screen crusher FC 02 work tool beyond the recommended maximum limit of $60 \mathrm{dBA}$ and the maximum allowed which is $70 \mathrm{dBA}$ so as to prevent problems of comfort, health, and safety at work. As well as suggesting operators and other employees at PT. Mifa Bersudara uses good PPE such as safety earmuffs when the Vibrating screen work tool is operated.

\section{References}

[1] Fadili, AA, Solihin, S., \& Moralista, E. (2020). Effect of Wire Screen Diameter on Production and Efficiency of Vibrating Screen in the Andesite Stone Crushing Plant Unit PT Nurmuda Cahaya East Batujajar Village, Batujajar District, West Bandung Regency, West Java Province.

[2] Hendrawan, AK (2020). Noise Analysis at the Nusantara Maritime Academy Workshop. Saintara: Scientific Journal of Maritime Sciences, 5(1).

[3] Jumsar, Tabang, KKD, \& Province, EK (2020). Evaluation of Crusher Productivity At Coal Processing Plant At Pt. Bara Tabang, Kutai Kartanegara Regency, East Kalimantan Province. Journal of Mineral Technology Ft Unmul, 8(1), 6-8.

[4] Kurniawati, SA, \& Yamin, M. (2013). Analysis of Noise and Mechanical Vibration on Saccof Harvester Machine (Case Study in Cimahpar Sugarcane Plantation, Bogor, West Java). Journal of Agricultural Engineering, 27(1).

[5] Kusmindari, Ch. D., 2008. The Effect of Noise Intensity on the Sugu Process and the Sanding Process on the Hearing of Workers in the Wood Workshop X. Jurnal Imiah TEKNO 5(2), 87 - 96.

[6] Luxson, M., Darlina, S. and Malaka, T., 2010. Noise in the workplace. Journal of Health Bina Husada, 6(2), pp.7585.

[7] Manullang, ALE, \& Handayani, NU (2015). Evaluation of Lighting, Noise, Temperature, And Vibration On Line 3 Pt South Pacific Viscose. Industrial Engineering Online Journal, 4(3).

[8] PT. MIFA Bersaudara (Persero), 2021. Industry | Update, Profile of PT. MIFA Bersaudara, Aceh Barat, July 2021, http://www.mifacoal.co.id/id-id/

[9 Saputra, AJ, 2007. Analysis of Factory Equipment Noise in Efforts to Improve Compliance with Occupational Safety and Health Regulations of PT. FERTILIZER KALTIM. [Thesis]. Diponegoro University.

[10] Suhardi, B., 2008. Work System Design and Industrial Ergonomics. Jakarta : Directorate of Vocational High School Development, Directorate General of Primary and Secondary Education Management, Ministry of National Education.

[11] Primary and Secondary Education Management, Ministry of National Education.

[12] Sukania, IW, 2013., Ergonomics Study of Bus Terminals in Jakarta. Scientific Journal of Industrial Engineering $1(1), 33-40$.

[13] H. Susanto, S. Ali, S. Ali, and M. Khalil, "Uji Getaran Rangka Tabung Sentrifugal Mesin Produksi Santan Kapasitas 10 Liter Per Jam,” J. Mekanova Mek. Inov. dan Teknol., vol. 7, no. 1, pp. 18-24, 2021

[14] Susanto, H., Munawir, A., \& Darsan, H. (2021). Uji Kebisingan pada Motor Listrik dan Tabung Sentifugal Mesin Produksi Santan Kapasitas 10 Liter Per Jam. Jurnal Mekanova: Mekanikal, Inovasi dan Teknologi, 7(1), 50-57.

[15] Zulfikri, S., \& Hasriyanti, N. (2020). Study on the Selection of Local Materials on Durability for Houses on the Riverside. Scientific Journal of Industrial Engineering. 